\title{
Prevention of domestic accidents in childhood: knowledge of caregivers at a health care facility
}

\author{
Prevenção de acidentes domésticos na infância: conhecimento de cuidadores em uma unidade de saúde \\ Prevención de accidentes domésticos en la infancia: conocimiento de cuidadores en un unidad de salud
}

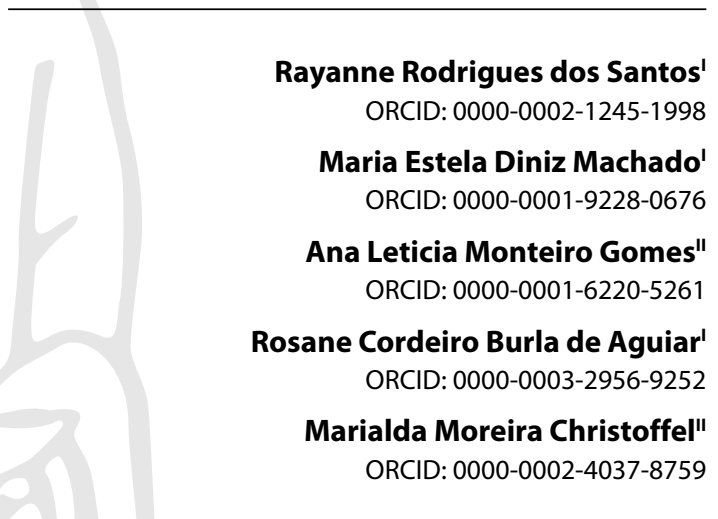

' Universidade Federal Fluminense. Niterói, Rio de Janeiro, Brazil.

"Universidade Federal do Rio de Janeiro. Rio de Janeiro,

Rio de Janeiro, Brazil.

How to cite this article:

Santos RR, Machado MED, Gomes ALM, Aguiar RCB

Christoffel MM. Prevention of domestic accidents in childhood: knowledge of caregivers at a health care facility. Rev Bras Enferm. 2022;75(2):e20210006 https://doi.org/10.1590/0034-7167-2021-0006

Corresponding author:

Rayanne Rodrigues dos Santos E-mail: rayannersantos@yahoo.com.br

EDITOR IN CHIEF: Dulce Barbosa ASSOCIATE EDITOR: Hugo Fernandes

Submission: $05-20-2020$

Approval: 05-09-2021

\begin{abstract}
Objective: To analyze caregivers' knowledge about prevention of domestic accidents in early childhood and its association with education level. Methods: This is a cross-sectional study conducted in a Primary Care Unit in Niterói with caregivers (convenience sample) of children under 6 years old. To classify the knowledge, we adopted the Positivity Index; to verify the association between the variable "schooling" and knowledge, the chi square test was used; statistically significant results: $p<0.05$. Results: A total of 256 caregivers participated; 93.5\% showed adequate knowledge. In the individual items, the knowledge (100\%) about prevention of accidents with sharp toys, firearms, intoxication by products stood out; and less frequently $(64.5 \%)$, the knowledge of the information contained in the Child's Health Booklet. There was no statistically significant association ( $p=0.237)$ between education and knowledge. Conclusion: The caregivers presented knowledge about the prevention of domestic accidents, and this was not associated with the level of education.

Descriptors: Child Health; Caregivers; Accident Prevention; Accidents, Home; Pediatric Nursing
\end{abstract}

\section{RESUMO}

Objetivo: Analisar o conhecimento de cuidadores sobre prevenção de acidentes domésticos na primeira infância e sua associação com nível de escolaridade. Métodos: Estudo transversal realizado em uma Unidade de Atenção Básica de Niterói com cuidadores (amostra por conveniência) de crianças menores de 6 anos. Para classificar o conhecimento, adotouse Índice de Positividade; para verificar a associação entre a variável "escolaridade" e o conhecimento, utilizou-se o teste qui quadrado. Resultados estatisticamente significativos: p < 0,05. Resultados: Participaram 256 cuidadores; 93,5\% apresentaram conhecimento adequado. Nos itens individuais, destacou-se o conhecimento (100\%) sobre prevenção de acidentes com brinquedos cortantes, armas de fogo, intoxicação por produtos; e menos frequente $(64,5 \%)$, o conhecimento das informações contidas na Caderneta de Saúde da Criança. Não houve associação estatística significante $(p=0,237)$ entre escolaridade e conhecimento. Conclusão: Os cuidadores apresentaram conhecimento sobre prevenção de acidentes domésticos, e este não esteve associado ao nível de escolaridade.

Descritores: Saúde da Criança; Cuidadores; Prevenção de Acidentes; Acidentes Domésticos; Enfermagem Pediátrica.

\section{RESUMEN}

Objetivo: Analizar el conocimiento de cuidadores sobre prevención de accidentes domésticos en la primera infancia y su relación con nivel de escolaridad. Método: Estudio transversal realizado en una Unidad de Atención Básica de Niterói con cuidadores (muestra por conveniencia) de niños menores de 6 años. Para clasificar el conocimiento, se adoptó Índice de Positividad; para verificar la relación entre la variable "escolaridad" y el conocimiento, se utilizó la prueba chi-cuadrado. Resultados estadísticamente significativos: $p<0,05$. Resultados: Participaron 256 cuidadores; 93,5\% presentaron conocimiento adecuado. En ítems individuales, destacó el conocimiento (100\%) sobre prevención de accidentes con juguetes cortantes, armas de fuego, intoxicación por productos; y menos frecuente $(64,5 \%)$, el conocimiento de informaciones contenidas en la Libreta de Salud Infantil. No hube relación estadística significante $(p=0,237)$ entre escolaridad y conocimiento. Conclusión: Los cuidadores presentaron conocimiento sobre prevención de accidentes domésticos, y esto no estuvo relacionado al nivel de escolaridad.

Descriptores: Salud del Niño; Cuidadores; Prevención de Accidentes; Accidentes Domésticos; Enfermería Pediátrica. 


\section{INTRODUCTION}

Accidents are considered unintentional injuries identified in traffic events, drowning, airway obstruction, poisoning, intoxication, burns, electric shock, firearm accidents, among others. They are responsible for high morbidity and mortality among children and adolescents, being considered a public health problem ${ }^{(1)}$. Not only emergency room visits are considered, since deaths are qualified up to 30 days after the accident, and hospitalizations are for at least 24 hours $^{(2)}$.

According to the World Health Organization, about 830,000 children die annually due to accidents that could have been prevented. The vast majority of these injuries occur in low- and middle-income countries ${ }^{(3)}$.

In Brazil, according to data from the Mortality System (MIS) of the Ministry of Health, in 2019, 3,568 people between the ages of zero and 14 died due to accidents, representing $7.3 \%$ of all deaths in this age group ${ }^{(4)}$. Among these deaths are various types of accidents, such as transportation, drowning, suffocation, assaults, and falls. Besides this, in the same year, approximately 113 thousand people from zero to 14 years of age were hospitalized due to accidents ${ }^{(2)}$.

Domestic accidents deserve to be highlighted, which are defined as all causal events independent of human will that occur in the environment comprising a house or home, including external areas (such as backyards) and also residences or long-stay institutions $s^{(5)}$. The rate of hospitalizations due to domestic accidents in early childhood registered in Brazil is $8 \%$, in Rio de Janeiro, 5.5\%, and in Niterói, 5.7\%. In mortality, the main cause is traffic accidents; and in hospitalizations, falls(6).

Children in early childhood (0 years to 6 years or 72 months) $)^{(7)}$, who are in a phase of great physical, cognitive, and social development, present a great risk of suffering accidents due to the need to move around in search of new experiences ${ }^{(8)}$. In addition, as they spend most of their time inside the home, they are in contact with environmental factors considered to be risk factors, such as wet floors, furniture with edges, glass, unprotected cribs, elevated beds, et $c^{(9)}$. Preventing the occurrence of unintentional injuries in the home environment requires continuous supervision and interventions aimed at reducing the child's exposure to these injuries ${ }^{(8)}$.

When it comes to children, there are several factors involved in the risk of unintentional injury in the home environment, such as age and gender, lack of adult supervision ${ }^{(10)}$, family socioeconomic level, risk behaviors adopted by the caregiver/family, accessibility and exposure to danger. Such factors may even be related to the caregivers' lack of knowledge about accident prevention ${ }^{(11)}$.

A research conducted in a pediatric university hospital in Venezuela characterized 112 cases of domestic accidents in children between 2 and 13 years old and identified the highest frequency of falls ( $34.9 \%)$, followed by burns $(25 \%)$ and poisoning $(21.4 \%)$, besides the highest occurrence in preschool age (46\%) and male predominance $(71 \%)^{(12)}$. This epidemiological characterization is important, because it provides data to guide the development of accident prevention actions.

A international study ${ }^{(13)}$ which evaluated the knowledge about child safety of 56 caregivers of children from 1 to 5 years old verified that there are still wrong daily practices, because only $29 \%$ of the caregivers presented all the adequate preventive attitudes regarding fall prevention. Despite the fact that child safety is a parental concern, wrong daily practices are still verified. Health professionals have a responsibility in this area, and should promote effective awareness programs and address the issue more regularly in child health consultations.

Health education is the best way to change habits, attitudes, behaviors that can be harmful to individual and/or collective health ${ }^{(14)}$. In this sense, the nurse excels in the development of educational actions, for caring and educating are inseparable roles in nursing practice ${ }^{(15)}$; therefore, this professional has the potential to contribute to the construction of knowledge and collaborate to improve the quality of life of the population. Child care demands meeting the special needs for growth and development, which include the promotion, surveillance, and monitoring of the child's health ${ }^{(16)}$.

This study aimed to analyze the knowledge of caregivers about prevention of domestic accidents in early childhood and its association with level of education. Thus, the problems presented through the results obtained can subsidize the nurse in the implementation of health education actions.

\section{METHODS}

\section{Ethical aspects}

This research complied with the ethical principles of Resolution 466/12 of the National Health Council/MH and was approved by the Research Ethics Committee of the Antônio Pedro University Hospital of the Federal Fluminense University.

\section{Study design, time and place}

Quantitative, cross-sectional study, guided by the STROBE tool and conducted in a health unit of the Primary Care Network of Niterói, Rio de Janeiro. The data collection period was from May 1 to October 31, 2018.

\section{Population and sample; inclusion and exclusion criteria}

The study population was composed of caregivers of children waiting for care in the immunization room. For sample calculation, the DIMAN 1.0 program was used, using the formula ${ }^{(17)}$, with a $95 \%$ confidence level and $5 \%$ error. The researched unit has an estimated attendance of around two thousand children/month, which, according to the sample calculation, would correspond to a total of 323 caregivers. However, due to difficulties during the data collection period (works in the vaccine room with consequent reduction in the number of users), the convenience sample was 256 participants. Inclusion criteria were: being a caregiver of children under six years of age and being over 18 years old. Exclusion criterion: not being literate, as it would make it impossible to read and fill out the questionnaire. None of the invited caregivers refused to participate or was excluded from the study.

\section{Study protocol}

For data collection, a self-administered structured questionnaire on the prevention of domestic accidents in childhood was prepared according to the guidelines of the Brazilian Society of Pediatrics ${ }^{(18)}$ and with information contained in the Child Health 
Handbook $(\mathrm{CHH})^{(8)}$. The questionnaire consisted of two parts: the first referred to the caregivers' sociodemographic characteristics, such as age, sex, education, and type of bond with the child; and the second was to capture the caregivers' knowledge with 17 assertions about the types of accidents and their forms of prevention, having as response items: "I agree" and "I disagree". The caregivers' knowledge was the main outcome of this study, whose exposure variable was the "education level" of these caregivers.

Pilot testing with five caregivers was conducted in order to verify the clarity and feasibility of the data collection questionnaire. In the end, it was not necessary to make adjustments to the questionnaire, and the five caregivers were included in the final sample of the study.

The collection was performed by the main author on a weekly basis and during the working hours of the vaccination room in the health unit, and the caregivers were invited to participate in the study through an individualized approach. At the time of collection, the privacy of those involved was guaranteed with the use of a separate room. The participants received orientation about the research, its objectives and questionnaire; then, they signed the Free and Informed Consent Term (FICT), assuring them the possibility of clarifying doubts at any moment. After collecting and checking the instruments, the data were entered into a Microsoft Excel spreadsheet 2010.

\section{Data analysis}

The data was analyzed by descriptive statistics in absolute and relative frequency for each assertion. The analysis of the caregivers' knowledge was given by the correct answers according to the researched literature ${ }^{(8-18)}$, represented by the word "yes" as a reference to having knowledge; and in the wrong answers, by the word "no" as a reference to not having presented knowledge. To qualify knowledge, the Positivity Index (PI) ${ }^{(19)}$ proposed by Carter ${ }^{(20)}$, which classifies the positive answers as follows: desirable (100\% positivity); adequate ( $99 \%$ to $90 \%$ positivity); safe ( $89 \%$ to $80 \%$ positivity); borderline $(79 \%$ to $71 \%$ positivity); and poor ( $70 \%$ or less positivity). Following these criteria, it was established for this study, as expected compliance, a PI higher than $80 \%$, which corresponds to a safe knowledge.

The verification of the data normality hypothesis was performed by the Shapiro Wilk test. To analyze the association of the categorical variable "level of education" with the caregivers" knowledge, Pearson's chi-square test or Fisher's exact test was used, depending on the characteristics of the observed frequencies through the representation of 1 point for "yes" answers and 0 value for "no" answers. The number of correct answers was calculated for each participant and, subsequently, the average number of correct answers per level of education. Results were considered statistically significant if they presented $\mathrm{p}$ values below 0.05 .

\section{RESULTS}

Of the 256 participants, females predominated with $88.3 \%$. The caregivers' age ranged from 19 to 73 years. As for education, $66.4 \%$ had higher education, being $31.6 \%$ had a graduate degree; 29.7\% had a high school education; and 3.9\% had completed elementary school. About the caregivers' relationship with the child, $89.1 \%$ were parents ( $77.8 \%$ mothers and $11.3 \%$ fathers); $10.1 \%$ grandparents; and $0.8 \%$ uncles and aunts.

Table 1 presents the results regarding the caregivers' knowledge about accidents in childhood and their classification according to the PI.

Table 1 - Knowledge of caregivers about domestic accidents in childhood according to the Positivity Index, Niterói, Rio de Janeiro, Brazil, 2018

\begin{tabular}{|c|c|c|c|c|c|}
\hline \multirow{3}{*}{ Items } & \multicolumn{4}{|c|}{ Knowledge } & \multirow{3}{*}{$\mathbf{P I}$} \\
\hline & \multicolumn{2}{|c|}{ Yes } & \multicolumn{2}{|c|}{ No } & \\
\hline & $\mathbf{n}$ & $\%$ & $\mathbf{n}$ & $\%$ & \\
\hline $\begin{array}{l}\text { 1. Children under four years of age should be kept away from any liquid reservoirs, which should be emptied after use, including } \\
\text { bathtubs, toilets, tanks, swimming pools and even buckets, as they can drown in liquid layers of } 5 \mathrm{~cm} \text {. }\end{array}$ & 220 & 85.9 & 36 & 14.1 & $\mathrm{~S}$ \\
\hline 2. It is not safe to leave children alone in pools, lakes, rivers or the sea, even if they can swim. & 255 & 99.6 & 1 & 0.4 & A \\
\hline 3. Plastic bags, cords, sheets, and pillows should not be left unsupervised near the child. & 216 & 84.4 & 40 & 15.6 & $\mathrm{~S}$ \\
\hline 4. Avoid using toys with small parts and keep small objects in the house out of children's reach. & 254 & 99.2 & 2 & 0.8 & A \\
\hline 5. The Inmetro seal guarantees that the toy has undergone tests that prove its safety and quality. & 239 & 93.4 & 17 & 6.6 & A \\
\hline $\begin{array}{l}\text { 6. In the kitchen, pans should be placed on the back burners of the stove, always with the handle facing the bottom and out of } \\
\text { reach of children. }\end{array}$ & 249 & 97.3 & 7 & 2.7 & A \\
\hline $\begin{array}{l}\text { 7. The ideal water temperature for the baby's comfort and safety is } 37^{\circ} \mathrm{C} \text {. You should test the water temperature with your hand } \\
\text { by moving it around the entire tub to make sure there are no spots that are too hot. }\end{array}$ & 205 & 80.1 & 51 & 19.9 & $\mathrm{~S}$ \\
\hline $\begin{array}{l}\text { 8. House wiring should be in good condition and tied up high, electrical outlets should be protected, and electrical appliances } \\
\text { should not be left in plugs or plugged in after use. }\end{array}$ & 248 & 96.9 & 8 & 3.1 & A \\
\hline $\begin{array}{l}\text { 9. Toys with sharp points or edges, guns with projectiles, darts and arrows should be kept out of children's reach as they can } \\
\text { cause injuries of varying severity. }\end{array}$ & 256 & 100 & 0 & 0 & $\mathrm{D}$ \\
\hline 10. 10. Sharp-edged or sharp objects should be kept in drawers and cabinets with locks out of children's sight and reach. & 255 & 99.6 & 1 & 0.4 & A \\
\hline 11. Furniture should have rounded corners. If they are sharp, the corners should be protected to prevent injury to the child. & 252 & 98.4 & 4 & 1.6 & A \\
\hline 12. Cleaning materials should be in their original containers and out of the reach of children, in high, locked cabinets. & 256 & 100 & 0 & 0 & $\mathrm{D}$ \\
\hline 13. Medicines should be kept out of the reach of children, in high, locked places. & 256 & 100 & 0 & 0 & $\mathrm{D}$ \\
\hline
\end{tabular}




\begin{tabular}{|c|c|c|c|c|c|}
\hline \multirow{3}{*}{ Items } & \multicolumn{4}{|c|}{ Knowledge } & \multirow{3}{*}{ PI } \\
\hline & \multicolumn{2}{|c|}{ Yes } & \multicolumn{2}{|c|}{ No } & \\
\hline & $\mathbf{n}$ & $\%$ & $\mathbf{n}$ & $\%$ & \\
\hline $\begin{array}{l}\text { 14. It is recommended to protect the cradle and the enclosure with high bars, with no more than } 6 \mathrm{~cm} \text { between one bar and } \\
\text { the other. }\end{array}$ & 241 & 94.1 & 15 & 5.9 & A \\
\hline $\begin{array}{l}\text { 15. Keep clear, constant lighting and adequate, non-slip flooring, with no rugs or objects that get in the way are measures that } \\
\text { can reduce the risk of falls. }\end{array}$ & 251 & 98 & 5 & 2 & A \\
\hline $\begin{array}{l}\text { 16. It is recommended that protective nets or bars be installed in all windows and/or balconies of apartments or houses with } \\
\text { two or more floors. }\end{array}$ & 252 & 98.4 & 4 & 1.6 & A \\
\hline 17. Information on accident prevention in childhood according to age group is present in the Child's Health Booklet. & 165 & 64.5 & 91 & 35.5 & $\mathrm{P}$ \\
\hline
\end{tabular}

Pl-positivity index (D-desirable; $A$ - adequate; $S$ - safe; $B$ - borderline; $P$ - poor.

Table 2 - Association between education level and caregivers' knowledge about domestic accidents in childhood, Niterói, Rio de Janeiro, Brazil, 2018

\begin{tabular}{|c|c|c|c|c|c|c|c|c|c|}
\hline \multirow[t]{2}{*}{ Level of education } & \multirow[t]{2}{*}{$\mathbf{n}$} & \multirow[t]{2}{*}{$\%$} & \multicolumn{2}{|c|}{ Yes } & \multicolumn{2}{|c|}{ No } & \multirow{2}{*}{ Average of hits } & \multirow{2}{*}{ SD } & \multirow{2}{*}{$p$} \\
\hline & & & $\mathbf{n}$ & $\%$ & $\mathbf{n}$ & $\%$ & & & \\
\hline Elementary school & 10 & 3.9 & 9.3 & 93 & 0.7 & 7 & 15.80 & 1.03 & \\
\hline Highschool & 76 & 29.7 & 71.1 & 93.5 & 4.9 & 6.5 & 15.99 & 1.34 & $0.237^{*}$ \\
\hline Higher Education & 89 & 34.8 & 82.7 & 93 & 6.3 & 7 & 15.99 & 1.19 & 0.231 \\
\hline Post graduation & 81 & 31.6 & 76.4 & 94.3 & 4.6 & 5.6 & 15.79 & 1.36 & \\
\hline
\end{tabular}

SD - standard deviation. ${ }^{*}$ Chi-square test.

In general, based on the average of all results, the participants of this study showed adequate knowledge (93.5\%) according to the PI. Among the surveyed items, the best results were about the caregivers' knowledge regarding injuries caused by sharp toys, firearms, and intoxication by cleaning products and medications, with $100 \%$ right answers (items $9,12,13$ ). The results related to the care with water reservoirs, materials that can cause suffocation, and temperature of the bath water (items 1, 3, 7) had a safe index of positivity (between 80 and $89 \%$ ), despite presenting a percentage of disagreement and lack of knowledge. The statement about the information on accident prevention in childhood contained in the $\mathrm{CHH}$ generated the lowest index of positivity, the sufferable (64.5\%).

There was no statistically significant association $(p=0.237)$ between education level and caregivers' knowledge about childhood domestic accidents.

\section{DISCUSSION}

In this study, although most (66.4\%) of the participants had higher education, there was no statistically significant association between the level of education and knowledge about accident prevention. The higher the caregivers' level of education, the greater the possibility of providing more effective safety practices and risk identification. However, other studies have not found significant association between high schooling of caregivers and adequate knowledge on accident prevention ${ }^{(13,21-22)}$, in line with the results evidenced in this study.

Multiple factors may be related to domestic accidents, such as not directly supervising the children; caregivers' resistance to change their behavior for accident prevention; unfavorable socioeconomic level; lack of orientation from health professionals $^{(22)}$; presence of tools, plastic bags, sharp materials arranged and accessible in the house; the type of furniture; free access to the places of greatest risk, such as kitchen, bathroom, balcony, windows, laundry room, swimming pools, etc.; the caregiver's own perception of the child's capacity to have a risk attitude related to his/her stage of development; among others ${ }^{(23)}$.

Regarding the risk of suffocation, the caregivers' knowledge was considered safe, however several circumstances can lead to the risk of suffocation, including with everyday items that apparently do not offer danger, such as pillows and sheet in the crib $^{(24)}$. The caregivers' knowledge was considered adequate regarding the risk of death by aspiration of foreign bodies through the airways, since children under four years of age present a high proportion of ingestion of small objects such as coins, toys, batteries, among others ${ }^{(25)}$. Accidents due to foreign body ingestion are related to the type of object, the environment, and the child's age, and the age group from zero to five years is the one with the highest risk for severity of airway obstruction.

To prevent these types of accidents, the use of the safety seal by age group of the National Institute of Metrology, Quality and Technology (Inmetro) is mandatory for all toys marketed in Brazil (whether domestic products or imported) used by children and adolescents up to 14 years of age; the goal is to avoid possible risks that may arise from normal use or as a result of improper use of the toy ${ }^{(26)}$. Some care should be taken by parents, such as: make sure that the toy's rating is appropriate for the age group; evaluate the size of the toy and whether it has small parts; check whether the battery or battery cover is screwed on; be careful with toys that look like food, because children can make associations and put them in their mouths.

The caregivers' PI was only "safe" regarding the temperature of the baby's bath, in line with the fact that scalds (injuries from heated liquids) are the main agents responsible for burns in the infant and child population. In children under 2 years, there is a predominance of bathing in superheated water ${ }^{(27)}$. Because the high temperature of the water in a bucket or bathtub poses a risk to the child, checking with a thermometer or the back of the caregiver's hand is indicated ${ }^{(28)}$. 
Caregivers obtained desirable knowledge regarding toys with sharp points or edges, guns with projectiles, darts, and arrows, which should be kept out of children's reach, as they can cause injuries of varying severity. In Brazil, a study ${ }^{(29)}$ which aimed to describe the actions of prevention of accidents in childhood performed by professionals of the Family Health Strategy showed that the issue of firearms was little addressed, since less than $50 \%$ of the participants said they had received guidance on the subject. Such a gap is also reflected in the scarcity of specific research on this issue in the Brazilian population and on the repercussion of this event on the victims' health ${ }^{(30)}$.

Studies show that accidents with cuts caused by sharp objects are among the main causes of domestic accidents and may be related to the lack of motor skills of children and to the level of awareness of caregivers about accident prevention ${ }^{(31-32)}$.

Regarding cleaning materials, the PI of the caregivers demonstrated desirable knowledge. It is noteworthy that cleaning product packages are often colorful and attract the child, even with a strong smell. In addition, the child who is in the oral stage will tend to bring to their mouth what they are attracted to. Therefore, storing dangerous substances out of the child's sight is fundamental; also, reducing the availability of toxic substances in the home and storing toxic substances in child-resistant packaging are proven measures for preventing poisoning ${ }^{(33)}$. Furthermore, many people reuse food packages to put hygiene and cleaning products, which favors this type of accident ${ }^{(34)}$.

Being aware of the health risks to children from ingesting cleaning products prevents situations like those described by the Regional Poison Control Centers in the United States and its territories. They received 72,947 calls related to exposures from liquid laundry detergent packaging between January 2012 and December 2017, occurring mostly in children under the age of $6(91.7 \%)^{(35)}$.

Children between one and four years old have a higher frequency of poisoning caused by cleaning products such as detergent, bleach and stain removers. It is recommended to keep these products in separate places that are difficult to access for children, not to use clandestine products and not to change the original packaging, so that, in case of ingestion, it is possible to contact the consumer service, in addition to the possibility of bringing the product to the attention of health professionals ${ }^{(34)}$.

Regarding medications, caregivers' knowledge was desirable. Knowing about the health risks and ways to prevent the inappropriate intake of medications is imperative when it comes to children. The intoxication/ poisoning by these substances is among the main causes of diseases in childhood, with a predominance of occurrence in the home environment and especially in the age group zero to four years ${ }^{(36)}$. Thus, the medications should be in places that are difficult to reach and out of the children's sight. The caregiver should also not take medications in front of children and refer to them as "candy" or use any other positive adjectives that arouse children's interest ${ }^{(34)}$.

The PI for the knowledge of caregivers attending the researched health care unit about information on accident prevention in $\mathrm{CHH}^{(8)}$ was poor. The $\mathrm{CHH}$ is the first document used by health services for the comprehensive monitoring of the child. It serves as a dialogical tool between professionals and family members, due to its applicability in the information and guidelines that are essential for the care and surveillance of child growth and development. This instrument subsidizes the implementation of comprehensive care for the child, since it provides guidance on danger signs to their health, information on growth and development, as well as accident prevention, among other actions ${ }^{(8)}$.

It is worth noting the existence of difficulties in the distribution of the $\mathrm{CHH}$ and its sometimes inadequate or incomplete use by health professionals. Studies ${ }^{(37)}$ show that less than $26 \%$ of the $\mathrm{CHH}$ s are adequately filled out. The highest rate of completion continues to be related to vaccines applied, and the lowest rates are related to neuro-psychomotor development, which configures its underutilization. Furthermore, there is a lack of involvement and participation of the family to monitor the growth and development of the child.

The nurse's performance through the nursing consultation in childcare in Primary Care aims to contribute to the quality of life of children, including actions to promote health and prevent disea$\operatorname{ses}^{(38)}$. The incorporation of $\mathrm{CHH}$ into this work process represents a support tool for child care during the nursing consultation, both in these actions and in the transmission of information to other health professionals at all levels of care and in health education and communication with the family ${ }^{(16)}$.

Health professionals often do not emphasize to caregivers the importance of $\mathrm{CHH}$ for obtaining information and monitoring the child's health. In the case of accident prevention, health professionals have great responsibility in educating and alerting the family, because holding this knowledge gives them great credibility ${ }^{(13)}$.

The results obtained in the sample evaluated were satisfactory, however accidents continue to happen in the home environment of the population ${ }^{(6)}$. One can consider the discordance between the caregivers' knowledge and practice associated to other factors possibly involved in the occurrence of unintentional injuries, such as: the idea of safety and comfort that the domestic environment offers; the lack of structure regarding the type of floors, style of furniture, unprotected windows and balconies, etc.; or even the lack of help in domestic chores and child care, often performed by a single person.

An American study ${ }^{(39)}$ explored how parents changed their homes to prevent recurrence after an unintentional injury with medical care. Most parents identified a prevention strategy, usually environmental (e.g., replace hazardous product storage); however, only 59 of 104 (56.7\%) made changes. That is, parents' knowledge of safety changes was generally consistent with best practices for injury prevention, but the low rate of change implementation represents a gap that future home accident prevention strategies can address.

Domestic accidents cause great damage to victims and their families, especially in cases of death and/or permanent disability ${ }^{(40)}$. For the State and society, accidents represent high costs to health services, with hospital admissions and rehabilitation ${ }^{(36)}$. Thus, the need for educational interventions with children's caregivers in the context of Primary Care is reinforced, since this is a favorable space for the development of these actions.

\section{Study limitations}

One of the limitations is the composition of the participants, which does not represent all the caregivers who attend the Basic Health Unit researched, taking into account the space and territory. Although the average positivity index is adequate for most participants, studies are needed to deepen the knowledge 
and practice in the prevention of accidents in childhood since this is a complex phenomenon.

\section{Contributions to the field of Nursing, Health or Public Policy}

The results presented bring more information about the weaknesses related to the caregivers' knowledge about accident prevention in early childhood. Although the general knowledge of most of them was considered safe, part of them is still unaware of crucial issues for the child's well-being, such as the need for the caregiver to supervise the child when he/she uses domestic water tanks and when he/she is in different situations in which asphyxia and burns can occur. In addition, the caregivers were unaware of the information on accident prevention contained in the $\mathrm{CHH}$, a tool for monitoring child development. Such findings direct important educational themes and reinforce the need for health professionals of Primary Care to adopt measures aimed at health education of the population to modify the situation found. Thus, these professionals can give more attention to the family network, ensuring the empowerment of the family through educational interventions that cover the prevention of domestic accidents during childcare visits and/or in the waiting rooms of health care services. Thus, they will ensure actions that address the fifth axis of the National Policy for Comprehensive Care of Child Health.

\section{CONCLUSION}

Based on the results obtained, it was possible to verify that the caregivers surveyed presented a high percentage of correct answers to the questions about the prevention of domestic accidents in childhood, with no association between the level of education and a higher number of correct answers on the prevention of domestic accidents.

Through the childcare consultation, the nurse is able to identify problems and implement conducts, and can use the $\mathrm{CHH}$ as an educational and facilitating tool regarding the main child care. The need to enhance the content and applicability of $\mathrm{CHH}$ in routine child care; the continuing education related to the theme for health professionals; and the promotion of health education actions for the population to reduce the child's physical and emotional impact generated by some type of accident during the process of growth and development are highlighted. Furthermore, it is expected that studies will be conducted to evaluate the practice of caregivers.

\section{REFERENCES}

1. Criança Segura Brasil. Plano nacional da primeira infância: projeto observatório nacional da primeira infância: mapeamento da ação finalística evitando acidentes na primeira infância [Internet]. Fortaleza: RNPI; 2014[cited 2019 Feb 10]. Available from: https://criancasegura.org.br/wpcontent/uploads/2016/08/03-1.pdf

2. Criança Segura Brasil. Dados sobre acidentes [Internet]. São Paulo: CSB; 2021[cited 2021 Feb 03]. Available from: http://www.criancasegura.org.br/ dados-sobre-acidentes

3. Peden M, Oyegbite K, Ozanne-Smit J, Hyde AA, Branch C, Fazlur Rahman AKM, et al. World report on child injury prevention [Internet]. Geneva: WHO Press; 2008[cited 2021 Apr 04]. Available from: https://www.who.int/violence_injury_prevention/child/injury/world_report/report/en/

4. Ministério da Saúde (BR), DATASUS. Informações de saúde: mortalidade [Internet]. Brasília, DF: MS: 2019[cited 2021 Apr 06]. Available from: http:// www2.datasus.gov.br/DATASUS/index.php?area=0205\&id=6937

5. Barreto JOM, coordenador. Prevenção de acidentes domésticos no Distrito Federal: edital FAPDF 07/2017 [Internet]. Brasília, DF: Fiocruz; 2019 [cited 2019 Apr 06]. Available from: https://www.arca.fiocruz.br/bitstream/icict/36920/2/Edital_FAPDF_072017_relatorio_acidentes_dom\%C3\%A9sticos.pdf

6. Ministério da Saúde (BR), DATASUS. Informações de saúde: morbidade hospitalar do SUS [Internet]. Brasília, DF: MS; 2017 [cited 2019 Jan 22]. Available from: http://www2.datasus.gov.br/DATASUS/index.php?area=0203\&id=6926

7. Ministério da Saúde (BR). Política nacional de atenção integral à saúde da criança [Interne]. Braślia, DF: MS; 2018[cited 2019 Jan 23]. Available from: https://portaldeboaspraticas.iff.fiocruz.br/wp-content/uploads/2018/07/Pol\%C3\%ADtica-Nacional-de-Aten\%C3\%A7\%C3\%A3o-Integral\%C3\%A0-Sa\%C3\%BAde-da-Crian\%C3\%A7a-PNAISC-Vers\%C3\%A3o-Eletr\%C3\%B4nica.pdf

8. Ministério da Saúde (BR). Caderneta da saúde da criança: menina: passaporte da cidadania [Internet]. 12a ed. Brasília, DF: MS; 2018 [cited 2019 Jan 23]. Available from: http://bvsms.saude.gov.br/bvs/publicacoes/caderneta_saude_crianca_menina_12ed.pdf

9. Brito MA, Melo AMN, Veras IC, Oliveira CMS, Bezerra MAR, Rocha SS. Risk factors in the domestic environment for falls in children under five years of age. Rev Gaucha Enferm. 2017;38(3):e2017-0001. https://doi.org/10.1590/1983-1447.2017.03.2017-0001

10. Ribeiro MGC, Paula ABR, Bezerra MAR, Rocha SS, Avelino FVSD, Gouveia MTO. Social determinants of health associated with childhood accidents at home: An integrative review. Rev Bras Enferm. 2019;72(1):265-76. https://doi.org/10.1590/0034-7167-2017-0641

11. Gurgel AKC, Monteiro AI. Domestic accident prevention for children: perceived susceptibility by the caregivers. Rev Pesqui: Cuid Fundam. 2016;8(4):5126-35. https://doi.org/10.9789/2175-5361.2016.v8i4.5126-5135

12. García B, Ramos I. Caracterización epidemiológica de los accidentes en el hogar. Bol Med Postgrado. 2020[cited 2021 Apr 02];36(2):53-58. Available from: https://docs.bvsalud.org/biblioref/2020/08/1117901/garcia-et-al.pdf

13. Silva SP, Sampaio J, Silva CT, Braga R. Segurança infantil dos 1 aos 5 anos: o que sabem os cuidadores?. Nascer crescer. 2017;26(4):221-6. https:// doi.org/10.25753/BirthGrowthMJ.v26.i4.10279 
14. Barreto ACO, Rebouças CBA, Aguiar MIF, Barbosa RB, Rocha SR, Cordeiro LM, et al. Perception of the primary care multiprofessional team on health education. Rev Bras Enferm. 2019;72(suppl 1):266-73. https://doi.org/10.1590/0034-7167-2017-0702

15. Vieira FS, Portela NLC, Sousa GC, Costa ES, Oliveira DEP, Neiva MJLM. Interrelationship of health education actions in the context of the family health strategy: nurses' perceptions. Rev Pesqui: Cuid Fundam. 2017;9(4):1139-44. https://doi.org/10.9789/2175-5361.2017.v9i4.1139-1144

16. Munhoz Gaíva MA, Monteschio CAC, Moreira MDS, Salge AKM. Child growth and development assessment in nursing consultation. Av Enferm. 2018;36(1):9-21. https://doi.org/10.15446/av.enferm.v36n1.62150

17. Arango HG. Bioestatística: teórica e computacional. 3a ed. Rio de Janeiro: Guanabara Koogan; 2009.

18. Sociedade Brasileira de Pediatria. Departamentos científicos [Internet]. Rio de Janeiro: SBP; 2014[cited 2019 Mar 14]. Available from: http://www. sbp.com.br/departamentos-cientificos/seguranca/

19. Derhun FM, Souza VS, Costa MAR, Inoue KC, Matsuda LM. Knowledge of nursing professionals regarding hand hygiene. Cogitare Enferm. 2016;21(3):1-7. https://doi.org/10.5380/ce.v21i3.45588

20. Saupe R, Horr L. Auditoria em enfermagem. Rev Cienc Saude. 1982;1(1):23.

21. Miranda IFA, Soares R, Torre K, Costa A, Fonseca T, Fernandes MG. Conhecimento dos responsáveis sobre a prevenção de acidentes domésticos envolvendo crianças. Rev Pediatr SOPERJ [Internet]. 2015[cited 2021 Apr 03];15(1):6-12. Available from: http://revistadepediatriasoperj.org.br/ detalhe_artigo.asp?id=638

22. Silva MF, Fontinele DRS, Oliveira AVS, Bezerra MAR, Rocha SS. Determining factors of domestic accidents in early childhood. J Hum Growth Dev. 2017;27(1):10-18. https://doi.org/10.7322/jhgd.127643

23. Bezerra MAR, Santos LR, Rocha RC, Rocha SS, Rodrigues AB, Brito ECC, et al. Perceptions that caregivers of children under five years of age have on the prevention of domestic accidents. REME. 2016;20:e944. https://doi.org/10.5935/1415-2762.20160014

24. Lima ICV, Pedrosa NL, Galvão MTG, Aguiar LFP, Paiva SS, Holanda ER. Domestic accidents and nursing diagnoses of children exposed to HIV at birth Esc Anna Nery. 2014;18(2):215-9. https://doi.org/10.5935/1414-8145.20140031

25. Brito JG, Pedroso BRP, Martins CBG. Domestic accidents by inanimate mechanical forces in children, adolescents and the young. Texto Contexto Enferm. 2016;25(2):e4180014. https://doi.org/10.1590/0104-07072016004180014

26. Instituto Nacional de Metrologia, Qualidade e Tecnologia (BR). Brinquedo: o porquê da certificação compulsória [Internet]. Brasília, DF: INMETRO; 2012[cited Mar 09]. Available from: http://www.inmetro.gov.br/imprensa/releases/brinquedo2.asp

27. Meschial WC, Sales CCF, Oliveira MLF. Fatores de risco e medidas de prevenção das queimaduras infantis: revisão integrativa da literatura. Rev Bras Queimaduras [Internet]. 2016[cited Mar 09];15(4):267-73. Available from: http://www.rbqueimaduras.com.br/how-to-cite/325/pt-BR

28. Brito JG, Martins CBG. Domestic burns among children, adolescents and young adults: urgency and emergency cases. Rev Eletronica Enferm. 2016;18:e1139. https://doi.org/10.5216/ree.v18.32141

29. Roma KMS, Gomes MFP, Reticena KO, Capellini VK, Fracolli LA. Prevenção de acidentes na primeira infância na estratégia saúde da família: perspectiva dos pais. Rev Enferm UFPI. 2018;7(2):28-34. https://doi.org/10.26694/2238-7234.7228-34

30. Ribeiro AP, Souza ER, Sousa CAM. Injuries caused by firearms treated at Brazilian urgent and emergency healthcare services. Cienc Saude Colet. 2017;22(9):2851-60. https://doi.org/10.1590/1413-81232017229.16492017

31. Filócomo FRF, Harada MJCS, Mantovani R, Ohara CVS. Profile of accidents in children and adolescents receiving care at a public hospital. Acta Paul Enferm. 2017;30(3):287-94. https://doi.org/10.1590/1982-0194201700044

32. Sirohi S, Pandey D, Dixit S, Jain C, Deshmankar B, Raja RS. Domestic accidents: an emerging threat to community. Int J Med Sci Public Health. 2015;4(9):1202-5. https://doi.org/10.5455/ijmsph.2015.14012015237

33. Ribeiro A, Barros M, Pereira IA, Lírio C, Pais IP, Couto ML. Conhecimentos e práticas parentais sobre medidas preventivas de acidentes domésticos e de viação. Rev Port Med Geral Fam. 2019;35(3):186-95. https://doi.org/10.32385/rpmgf.v35i3.12286

34. Brito JG, Martins CBG. Accidental intoxication of the infant-juvenile population in households: profiles of emergency care. Rev Esc Enferm USP. 2015;49(3):373-80. https://doi.org/10.1590/S0080-623420150000300003

35. Gaw CE, Spiller HA, Casavant MJ, Chounthirath T, Smith GA. Safety interventions and liquid laundry detergent packet exposures. Pediatrics. 2019;144(1):e20183117.https://doi.org/10.1542/peds.2018-3117

36. Rodrigues CL, Armond JE, lamarino APM, Santos ACG, Armond RE, Górios C. Análise das notificações de acidentes pediátricos na cidade de São Paulo. Rev Atenc Saude. 2017;15(51):52-6. https://doi.org/10.13037/ras.vol15n51.4270

37. Freitas JLG, Pereira PPS, Moreira KFA, Órfão NH, Cavalcante DFB, Nascimento RC, et al. Completion of the child health record book in early childhood. Rev Bras Promoc Saude. 2019;32:8407. https://doi.org/10.5020/18061230.2019.8407

38. Sobral MGV, Pessoa VLMP, Florêncio RS, Solon AAIB, Bento JNC, Cestari VRF, et al. Essential elements of the child and adolescent nursing consultation. Rev Enferm UFPE. 2018;12(12):3464-75. https://doi.org/10.5205/1981-8963-v12i12a235064p3464-3475-2018

39. Jones VC, Shields W, Ayyagari R, Frattaroli S, McDonald EM, Gielen AC. Association between unintentional child injury in the home and parental implementation of modifications for safety. JAMA Pediatr. 2018;172(12):1189-90. https://dx.doi.org/10.1001/jamapediatrics.2018.2781

40. Simas VFC, Souza AS. Crianças hospitalizadas vítimas de acidentes na primeira infância. Rev Pró-UniverSUS. 2019;10(1):25-8. https://doi. org/10.21727/rpu.v10i1.1633 